\title{
STRATEGI PEMBANGUNAN EKONOMI BERBASIS SISTEM AL-MAQASHID
}

\author{
Asmuni, Mth \\ Dosen Prodi Hukum Islam FIAI UII, kandidat Doktor UIN Sunan Kalijaga Yogyakarta \\ email: asmuni_uii@yahoo.com
}

\section{ABSTRACT}

The economic crises are occurred not only in the developing countries, but also in the developed ones. The signals provide a strong approval that economic based on capitalism and socialism has failed to create prosperity and to humanize the human-being themselves. Furthermore, Moslem countries which are the victims of both capitalism and socialism are getting sufferer, since they are trapped on foreign loan with high interest accumulation. Consequently, those Moslem countries cannot develop themselves, for their natural resources are more given to the developed countries as compensation and investment. The remaining is for foreign loan payment and is often corrupted. If collaboration is established based on a mutual interest, foreign hegemony towards the developing countries is not occurred. From this point, it is important to develop economy using the maqashid system which is planning and involving the substantial problem. The system proposes the investment loan must be used to develop productive sectors, such as infrastructure and facilities of education and training in order that the society has skill to live independent, and capable to improve their prosperity.

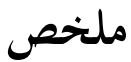

وقوع الأزمات الاقتصادية ليس فقط في البلدان النامية، ولكن أيضا في البلدان المتقدمة. توفرتالإشارات على موافقة قوية أن الاقتصاد على أساس الرأسمالية والاشتراكية فشل في تحقيق الرخاء والرفاهية وجعل الناس كالناس. وعلاوة على ذلك، فإن دول المسلمكضحايا كل من الرأسمالية والاشتراكية إزداد تألمهن، لأها محاصرون على سبيل الإعارة الخارجية مع تراكم الفائدة المرتفعة. ونتيجة ذالك، لا تمكندول المسلمأن تطور أنفسهن، لأن أكثر مواردهن الطبيعية تعطى إلى الدول المتقدمة 


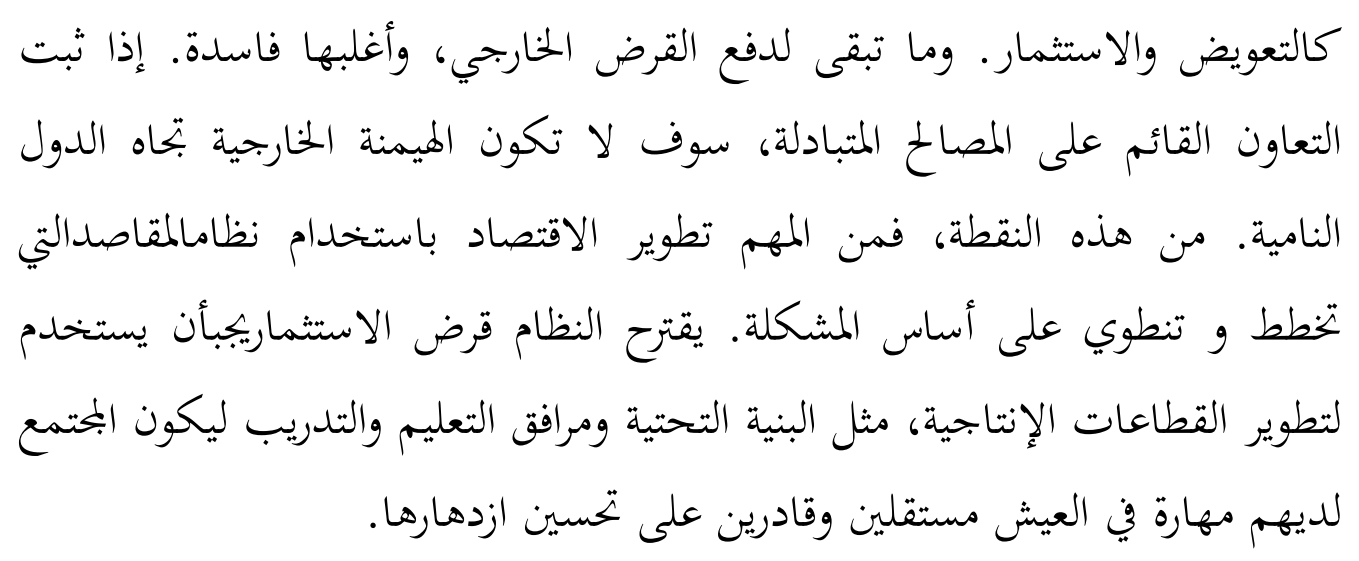

Key words: al-maqashid, pembangunan, kapitalisme, sosialisme.

\section{A. Pendahuluan}

Berdasarkan hasil penelitiannya, Thomas Piketty membuktikan bahwa kapitalisme telah membentuk ketimpangan atau jurang antara si kaya dengan si miskin semakin besar. ${ }^{1}$ Cara mengukurnya cukup sederhana,yaitu dengan membandingkan rate of return dengan tingkat pertumbuhan (growth) ekonomi suatu negara. Rumusnya adalah nilai rate of return lebih besar dari pada growth ( $r>g$ ). Dengan kata lain, pada saat pasar yang dikuasai oleh pemilik modal meraup keuntungan besar, tidak akan pernah sebanding dengan nilai pertumbuhan ekonomi yang diperoleh suatu negara. Dalam kondisi tersebut, negara-negara berkembang biasanya akan mengalami bagaimana ketimpangan ekonomi, kemiskinan, pengangguran dan lain sebagainya sebagai "hantu" di balik pertumbuhan ekonomi yang ditargetkan.

Mengikuti tesis tersebut, adalah sangat wajar dipahami bila setiap krisis ekonomi akan diikuti oleh gejolak politik. Krisis ekonomi 1997 misalnya, menghantarkan gejolak politik dengan ditumbangkannya presiden Soeharto. Pada saat subrame mortage mengancam Amerika Serikat, diikuti oleh gejolak politik bertajuk "demokratisasi" di kawasan Timur Tengah yang berujung perang saudara, konflik agama dan semua itu bukannya memperbaiki kondisi, sebaliknya

1 Thomas Piketty, Capital in the Twenty-First Century, ( Cambridge : Harvard Univercity Press, 2014). 
memperkeruh keadaan. ${ }^{2}$ Kondisi ini, berdasarkan prinsip liberalisasi dalam semangat globalisasi, ibarat melepas ular besar ke kandang kambing. Bagi ular, kambing tersebut adalah mainan yang mengasyikkan sekaligus mengenyangkan, namun sebaliknya keberadaan ular adalah ancaman bagi kehidupannya. Ular akan terus mengancam mangsanya, sekalipun ia tengah tidur kekenyangan. ${ }^{3}$

Terkait dengan tulisan ini, pertanyaannya adalah bagaimanakah realitas umat muslim di tengah arus besar liberalisasi ekonomi dan politik tersebut? Langkah apa yang telah dilakukan, sebagai contoh oleh negara Republik Indonesia yang mayoritas muslim dalam menghadang arus "McDonalisasi" tata kehidupan saat ini? Dua pertanyaan ini dijawab dengan pendekatan sistem maqashid. Sekalipun pendekatan ini cukup klasik dan telah banyak upaya memperbaharuinya, namun sedikit yang memposisikan maqashid dalam kerangka teori sistem. Sasaran pokoknya adalah bagaimana merancang sistem strategis dalam konsep pembangunan untuk negara ketiga yang pada umumnya dihuni oleh mayoritas penduduk muslim.

\section{B. Realitas Umat Muslim; Menengok Kondisi Indonesia}

Jika diperhatikan, hampir seluruh negara muslim masuk dalam kategori sebagai negara ketiga. ${ }^{4}$ Sekalipun memiliki struktur yang berbeda, dapat dipastikan mereka menghadapi masalah-masalah yang hampir sama berhubungan dengan ekonomi. Sebutlah misalnya persoalan makro ekonomi yang ditandai

2 Tentang revolusi sipil Timur Tengah lihat: Cahyo, Agus N., Tokoh-Tokoh Timur Tengah yang Diam-Diam Jadi Antek Amerika dan Sekutunya, , (Yogyakarta: DIVA Press, 2011). Hendrajit Dkk, Tangan-Tangan Amerika Operasi Siluman di Pelbagai Belahan Dunia, (Jakarta: Global Future Institute, 2010). Ricardo, David Akhmad, Khadafi Jagoan Tanah Arab, (Makassar: Arus Timur).

3 Uraian bagus tentang kerakusan dan dominasi Barat terhadap ekonomi negara-negara berkembang dapat dilihat dalam: Perkins, John, Confessions of An Economic Hit Man, San Francisco: BK: Barrett Koehler Publishers, 2004, dan The Secret History of The American Empire Economic Hit Man, Jackals and The Truth About Global Corruption, diterjemahkan ke dalam bahasa Indonesia oleh Wawan Eko Yulianto \& Meda Satrio, (Jakarta: Ufuk Press, 2007).

4 Uraian tentang kemiskinan dapat dilihat dalam: Agenda Ekonomi Kerakyatan, Revrisond Baswir, Pengantar Dr.Srutua Arief, Pustaka Pelajar bekerjasama IDEA (Institute of Development and Economic Analysis), Yogyakarta, 1997, hal. 17. 
dengan tingginya tingkat pengangguran dan inflasi, defisit neraca pembayaran, depresiasi nilai mata uang, beban utang yang besar. Sebaliknya, realitas sosio-ekonomi menunjukkan adanya ketimpangan sosial yang tinggi dan tidak meratanya kesejahteraan dengan ditandai oleh kemiskinan, rendahnya pendidikan dan etos kerja, dan berujung pada rendahnya pendapatan sehingga tidak mampu memenuhi kebutuhan dasar dan lain sebagainya.

Indonesia, misalnya. Selama ini, pembangunan Indonesia tersendera oleh paradigma pembangunan ketergantungan yang menegaskan bahwa pembangunan di negara berkembang sangat tergantung pada kerja sama atau peran negara maju yang "menginvestasikan" teknologi. Indonesia, sebagaimana jauh hari ditegaskan oleh Sritura Arif, belum mampu keluar dari pihak asing. Bahkan sumber daya penting yang terkandung di perut bumi Indonesia hampir sepenuhnya dikuasai oleh pihak asing. Dahulu, negara ini terkenal sebagai pengekspor beras, tapi kini justeru menjadi pengimpor; bahkan dari negara seperti Vietnam. Celakanya, sebagai negara maritim, Indonesia sempat menjadi pengimpor garam yang bahan bakunya adalah air laut. Agaknya, keterjebakan ke dalam nalar ketergantungan ini, dimanfaatkan oleh sementara jamaah "oknum" elit penguasa untuk meraup keuntungan pribadi. Persis pada titik itu, saat ini, Indonesia tengah menghadapi triple crises, yaitu di bidang: energi, pangan dan keuangan, demikian ditegaskan oleh Dawam Rahardjo.

Satu contoh pada sektor energi. Indonesia pernah dimanjakan oleh booming harga minyak pada 1970-an. Pada saat itu, pembangunan didefenisikan sebagai industrialisasi untuk kemudian mengimpor berbagai produk luar, khususnya berkaitan degan teknologi. Di awal 1980-an, eforia tersebut muncullah kebijakan memperkencang 'ikat pinggang'. Pasalnya, harga minyak kembali turun dan produksi minyak Indonesia mulai melemah. Berturut-turut, hingga saat ini, Indonesia justeru menjadi pengimpor minyak sekalipun memiliki ladang minyak yang cukup banyak. Walhasil, anggaran belanja negara tercekik oleh subsidi. Kondisi ini, dijadikan dalih untuk mengurangi subsidi dan menaikkan harga minyak di pasar. Padahal, tata kelola hulu energi, mulai dari peraturan perundang-undangan, kebijakan, hingga infrastrukturnya berantakan, dikuasai oleh mafia migas, namun seolah tak dapat disentuh. Justeru, pemerintah ke pemerintah, melestarikan kebijakan neoliberal (menyerahkan harga pada pasar) atas dalih anggaran. Tentu yang tersenyum lebar adalah para mafia 
migas, karena selain mendapat untung lebih dari ekspor-impor, juga bisa ikut bermain di sektor pengisian bbm. Pertanyaannya, dalam kondisi demikian, apakah Indonesia sanggup bersaing dengan negara kawasan dalam mempertahankan kedaulatan ekonomi negara, mengingat Indonesia termasuk sebagai negara yang memiliki sumber energi yang banyak?Ketimpangan ekonomi di Indonesia setidaknya dapat dilihat pada gini ratio dan tingkat korupsi. Hingga saat ini, Index Gini menunjukkan bahwa kesenjangan (inequality) ekonomi di Indonesia masih tinggi, sehingga berdampak pula terhadap kesenjangan sosial, pendidikan, dan lain sebagainya. Perhatikan table gini ratio di bawah ini! Sejak tahun 2006, terjadi peningkatan kesenjangan dengan nilai gini pada tahun 2013 adalah $0.41 \%$. Dalam kondisi kesenjangan ini, dapat dipastikan yang kaya semakin kaya, dan yang miskin semakin miskin. 29 juta berada dalam kondisi kemiskinan absolut, 11,5\% dari total penduduk Indonesia berada pada posisi kemiskinan relative.

\begin{tabular}{|l|r|r|r|r|r|r|r|r|}
\hline & $\mathbf{2 0 0 6}$ & $\mathbf{2 0 0 7}$ & $\mathbf{2 0 0 8}$ & $\mathbf{2 0 0 9}$ & $\mathbf{2 0 1 0}$ & $\mathbf{2 0 1 1}$ & $\mathbf{2 0 1 2}$ & $\mathbf{2 0 1 3}$ \\
\hline Gini Ratio & $0.36 \%$ & $0.36 \%$ & $0.35 \%$ & $0.37 \%$ & $0.38 \%$ & $0.41 \%$ & $0.41 \%$ & $0.41 \%$ \\
\hline
\end{tabular}

Sources: Statistik Indonesia

Pada posisi yang lain, angka korupsi Indonesia terbilang sangat tinggi. Dengan berada pada posisi 118 negara terkorup dari 176 negara berdasarkan penilaian Transparency International Corruption Perception Index 2012, Indonesia boleh dikatakan berada pada era 'jahiliyah modern' yang lebih 'jahiliyah' dibandingkan zaman jahiliyah yang dihadapi Rasulullah saw. Karena kejahiliyahan modern dilakoni oleh orang-orang yang tidak hanya berpendidikan, namun juga beragama. 


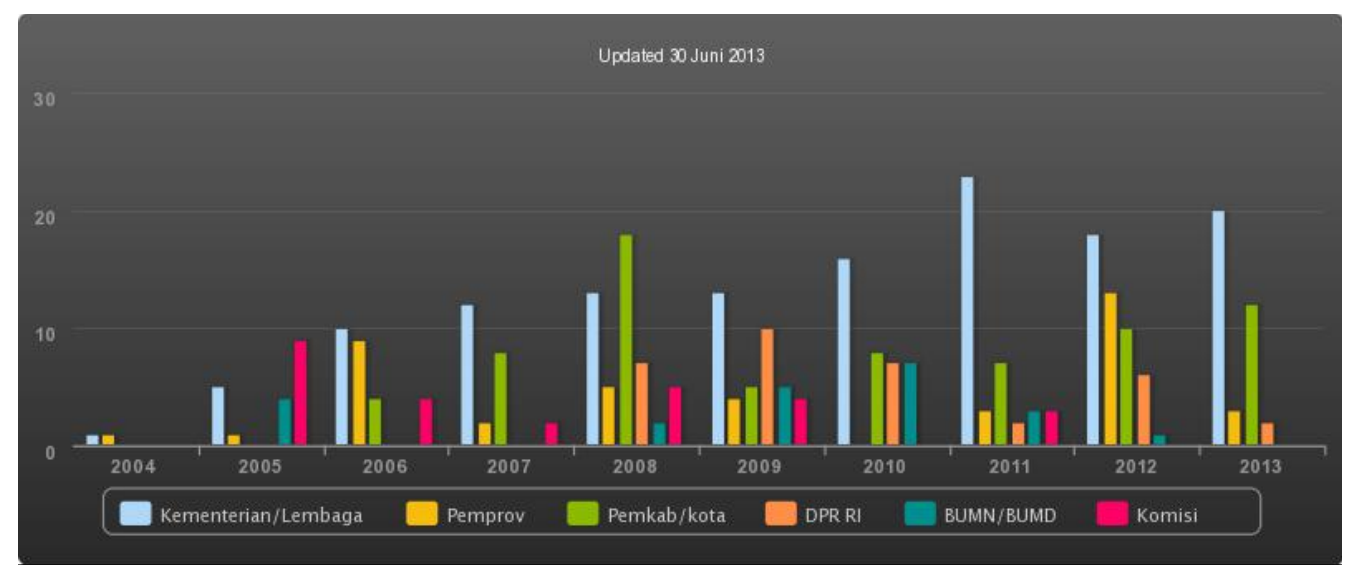

Grafik 1. Penanganan TPK Berdasarkan Instansi

Sumber: http:/ /acch.kpk.go.id/statistik-penanganan-tindak-pidana-korupsi-berdasarkan-instansi

Data di atas mempertegas bahwa korupsi telah terdistribusi ke tingkat lokal melalui saluran otonomi daerah yang minim akuntabilitas, yang hingga juni 2013 secara keseluruhan tercatat 320 kasus. Akan tetapi, pada titik yang lain, otonomi daerah yang dijalankan dengan akuntabilitas, transparansi yang baik, cukup memberikan dampak bagi pembangunan daerah. Memperkuat data ini, Indonesian Corruption Watch mengeluarkan data korupsi kepala daerah berdasarkan partai pengusung. Tahun 2012, ICW mencatat terdapat 147 kasus korupsi kepala daerah. Para elit politik banyak terjebak kasus, dan didominasi oleh partai penguasa.

Penelitian dan Pelatihan Ekonomika dan Bisnis (P2EB) Fakultas Ekonomika dan Bisnis UGM, merilis hasil analisis terhadap 1365 kasus korupsi dari tahun 2001-2012 yang sudah mendapatkan putusan tetap dari Mahkamah Agung. ${ }^{5}$ Kerugian negara dari kasus-kasus tersebut adalah 168,19 triliun. Kerugian ini belum termasuk hasil jarahan korporasi asing yang begitu massif melalui state capture corruption. Kekayaan Indonesia, baik yang ada di darat, laut, dan udara dijarah sedemikian rupa dan ironisnya justeru "dilegalkan" negara. Ini dapat dilihat dalam berbagai Undang-Undang yang bukannya mensejahterakan rakyat, namun justeru membuka lebar pihak asing menjarah Indonesia.

Berdasarkan dua data di atas (gini ratio dan tingkat korupsi), dapat dipahami bahwa perilaku komponen dalam sistem pembangunan di Indonesia

5 http://www.tempo.co/read/news/2013/03/04/058464996 
bergerak pada dua pola, yaitu minimum. Perilaku minimum tercermin pada begitu lebarnya jarak antara yang kaya dan miskin dengan membentuk struktur masyarakat piramida. Banyak yang miskin, sedang yang kaya sangat sedikit. Kondisi ini melahirkan sikap mental yang minimum, tidak memenuhi persyaratan untuk menggerakkan sistem dengan baik. Tingginya korupsi yang dilakukan para elit ekonomi dan rendahnya etos kerja, menjadikan pembangunan seakan ada namun hakikatnya tidak ada. Ada namun terkonsentrasi pada satu titik, tidak ada karena mayoritas masyarakat belum menikmati hasil pembangunan yang digadang-gadangkan. Karena kemiskinan secara otomatis berdampak pada rendahnya pendidikan, tidak berketerampilan, dan lain sebagainya.

\section{Kegagalan Strategi yang Diadopsi}

Setiap sistem ekonomi memiliki nilai dan landasan filosofi yang dengannya sebuah sistem dibentuk dan dilaksanakan. Sebutlah misalnya sistem ekonomi Pancasila. Nilai dan landasan filosofinya termaktub dalam tiap-tiap sila dan butir-butir pengamalannya. Dengan nilai dan landasan filosofi itu, suatu sistem ekonomi setidaknya harus memiliki: (a) mekanisme preventif guna menghindari segala bentuk tindakan eksploitasi dan diskriminasi yang dengannya tujuan dari aktifitas sosio-ekonomi diarahkan; (b) nilai etos yang tinggi guna mendorong setiap individu dan masyarakat untuk mewujudkan kesejahteraan bersama; dan (c) media atau saluran distribusi untuk mengalokasikan sumber daya yang ada demi tercapainya tujuan. Oleh sebab itu, nilai dan dasar filosofi ini harus kokoh dan konsisten, sehingga pengejah-wentahannya ke dalam konsep dan strategi pembangunan dapat berjalan dengan baik.

Indonesia diakui atau tidak selama ini telah mencoba melaksanakan strategi-strategi pembangunan dikonsepsikan dalam sekulerisme dan perspektif kapitalisme serta sosialisme. Akan tetapi permasalahan menjadi semakin memburuk dan negeri ini telah bergerak menjauh dan semakin menjauh dari maqashid. Alasan utamanya adalah bahwa strategi-strategi, yang diadopsi, telah dipinjam dari masyarakat yang memiliki tujuan-tujuan yang mungkin sama dengan tujuan-tujuan dalam Islam, namun filosofis dasar dan starteginya tidak sesuai dengan perwujudan dari tujuan-tujuan tersebut. 
Kapitalisme menganggap kepentingan individu sebagai kekuatan motivasi atau spirit utama yang mendorong aktifitas ekonomi. Berdasarkan nilai ini, kapitalisme menandaskan bahwa setiap individu memiliki kebebasan untuk memaksimalisasi kepuasan, keuntungan, kepemilikan harta, tanpa terikat pada rasa kepedulian sosial. Pasar menjadi tempat, baik bagi konsumen maupun produsen untuk mewujudkan tujuan maksimalisasi dan meminimalisasi resiko dan biaya.

Bagaimana mungkin hal demikian bisa terjadi? Tak lain adalah karena kerangka asumsi-asumsi yang menegaskan bahwa: pertama, apapun bentuk kepentingan sosial dilakukan atas dasar motif atau untuk kepentingan pribadi; kedua, oleh sebab itu, perlu sarana sekularisasi guna mengharmoniskan dua kepentingan yang berbeda agar tidak terjadi konflik yang lazim disebut "pasar" di mana setiap orang memiliki hak dan kebebasan yang sama untuk mendapatkan tujuannya; ketiga, terpenuhinya motif-motif individu, secara otomotis merefleksikan terbentuknya tatanan sosial yang baik. Akan tetapi, ketiga asumsi ini tidak dapat dibenarkan, mengingat kapitalisme dengan instrument yang dimilikinya telah melakukan eksploitasi dan dehumanisasi yang akut.

Sosialisme dengan semangat "komunalnya" bertujuan membentuk masyarakat tanpa kelas sebagaimana telah diakibatkan oleh kapitalisme. Caranya adalah dengan menghapus kepemilikan pribadi dan apapun motif yang hanya mementingkan keuntungan pribadi dianggap sebagai semangat yang bertentangan dengan kepentingan sosial. Pemerintah memegang kendali terhadap seluruh sumber daya yang ada, baik dalam pemanfaatan maupun mendistribusikannya kepada masyarakat. Akan tetapi, sentralisme seperti ini justeru menjadikan roda ekonomi tidak berjalan, sebaliknya malah membentuk sistem pemerintahan yang tiran dan otoriter. Dalam kondisi seperti itu, ketimpangan akan tetap ada, seturut dengan adanya konflik sosial.

Kelemahan logis dari sosialisme dan kapitalisme juga terlihat dari faktanya. Pengalaman dari negara-negara kapitalis menunjukkan bahwa sekalipun mereka paling kaya dan sangat maju namun belum mampu menghilangkan kemiskinan dan memenuhi kebutuhan, meskipun sudah lama berkembang dan kekayaan yang melimpah pada masyarakatnya. Ketimpangan pendapatan dan kekayaan kenyataannya muncul, dan pengangguran telah menjadi permasalahan jangka panjang dan kronis. Beberapa negara ini juga sedang meng- 
hadapi ketimpangan eksternal dan makroekonomi yang kronis, yang sulit mereka hilangkan. Catatan dari negara-negara sosialis juga tidak berbeda dalam hal pemenuhan kebutuhan untuk mengurangi ketimpangan sosial ekonomi meskipun sumber dayanya melimpah. Perekonomiannya cenderung stagnan karena kurangnya motivasi antara pekerja dan eksekutif serta ketidakmapuan dari sistem tersebut untuk menjawab realitas perubahan. Utang-utang dari negara-negara ini juga meningkat tajam seperti halnya sejumlah negara-negara berkembang. Adopsi dari solusi pasar, dimana perestroika tunjukkan, dalam kerangka sekularisme dari masyarakat terikat dan memaksanya terlibat dalam persoalan inflasi, pengangguran dan ketimpangan ekonomi lainnya dimana masyarakat kapitalis mengalami sendiri.

Maka kedua sistem tersebut telah gagal mewujudkan tujuan-tujuan yang ditetapkan. Sebabnya adalah bahwa filosofis dasarnya dari kehidupan dan strateginya tidak sesuai dengan tujuan-tujuan yang ditetapkan tersebut. Tujuannya adalah berprikemanusiaan tetapi strategi-strateginya berorientasi konflik berdasarkan atas social Darwinism atau dialektika daripada atas dasar konsep kebersamaan antar manusia, tanggung jawab terhadap sumber-sumber alam kepada yang Maha Tinggi. Dengan kerangka referensi tentang pandangan dan strateginya, mereka tidak mampu memperkenalkan perubahan-perubahan struktural yang radikal yang diperlukan untuk mewujudkan tujuan-tujuan yang ditetapkan tanpa menonjolkan ketimpangan makroekonomi. Sistemsistem yang telah gagal diwujudkan tidak dapat dijadikan sebagai contoh bagi Indonesia, bahkan bagi negara-negara Muslim lainnya. Oleh karena itulah, negara-negara Muslim harus kembali dan melihat apakah Islam mampu memberikan satu sistem yang membantu menghasilkan alokasi dan distribusi sumber-sumber daya tersebut yang berbeda dari kedua sistem di atas dan sejalan dengan maqashid syariah.

\section{Al-Maqâsid Sebagai Sistem Pembangunan Komprehensif}

Al-Maqâșid sesungguhnya bukanlah disiplin ilmu baru, terutama jika diposisikan dalam ruang lingkup ilmu ushul al-fiqh. Geneologi teorisasi al-maqâs id telah memakan rentang waktu yang lama, dengan berbagai dinamika dan dialektika antara pihak yang pro dan kontra, liberal-radikal, maupun mereka yang mengambil posisi tengah. Konstruksi ilmu maqâșid mulai terstruktur secara 
lebih baik di tangan al-Syatibi. Akan tetapi, ia tetap saja menjadi disiplin yang belum selesai. Terlebih jika dikaitkan dalam konteks pengembangan ekonomi syari'ah. Para ahli ushul, ahli ekonomi Islam, dan lainnya belum bertemu pada satu titik kesepakatan dalam memposisikan al-maqâsșid sebagai metode analisa atau sebagai general principle.

Kebelum selesaian itu, tampak jelas dengan terjebaknya maqâșid ke dalam nalar utilitarianisme. Maslahah seolah menjadi instrumen untuk menyatakan segala sesuatu, sepanjang memiliki nilai maslahah maka mendapatkan legitimasi syari' ah. Pada ujungnya, argument maslahah tersebut terperangkap pada kasus-kasus tertentu, bersifat individual atau berpretensi pada kelompok tertentu, sehingga acapkali tidak mampu menjawab persoalan komunitas, baik pada level local, nasional, terlebih internasional.

Pada titik tersebut, diperlukan upaya pemikiran ulang teorisasi al-maqâs id sebagai sebuah sistem pembangunan. Sekalipun sekedar pengantar, ulasan singkat berikut diharapkan mampu menjelaskan the ideal state of socio, cultural and economic development based on maqashid al-syari'ah. Syarat utama pembentukan tatanan ideal bagi sistem pembangunan, adalah dengan menentukan komponen-komponen apa saja yang menentukan terlaksananya pembangunan tersebut. Sebagaimana dijelaskan oleh Husni Muadz ${ }^{6}$, masingmasing komponen merupakan satu kesatuan yang utuh dan akan membentuk relasi invariant (tetap) yang secara terus menerus akan melahirkan emergent properties. Berdasarkan sudut pandang ini, maka mașlahah tidak lagi dijadikan sebagai tujuan. Melainkan emergent properties dari terpeliharanya relasi invariant antar komponen. Relasi tersebut merupakan relasi intersubyektifitas yang bersifat terus menerus, unity dan terintegrasi. Lalu, apa yang menjadi komponennya?

Sistem pembangunan dalam perspektif maqâșid adalah berbasis pada pembelajaran berkelanjutan (long time learning). Tujuannya adalah untuk memanusiakan manusia; meletakkan manusia pada prinsip kedalaman, yaitu bahwa manusia bukanlah terbatas sebagai makhluk materi yang berada pada alam kehidupan. Lebih dari itu, ia memiliki kesadaran bahkan manusia adalah makhluk spiritual yang memiliki pengalaman di dunia materi. Berdasarkan

$6 \quad$ M. Husni Muadz, Anatomi Sistem Sosial Rekonstruksi Normalitas Relasi Intersubyektivitas dengan Pendekatan Sistem, (Mataram: Institut Pembelajaran Gelar Hidup [IPGHI], 2014). 
perspektif ini, pembangunan tidak lagi diarahkan pada upaya penumpukan materi, eksploitasi alam, yang pada ujungnya menimbulkan berbagai bentuk ketimpangan, kerusakan, ketidak-teraturan. Lebih jauh, menciptakan dehumanisasi terhadap manusia. Di sini, dapat dipahami bahwa komponen dasar bagi pembangunan adalah manusia itu sendiri. Akan tetapi, ia tidak dilihat sebatas makluk individu karena sikap ini melahirkan sikap individualis-utilitarianism.

Menggunakan perspektif Jamaluddin al-Ațiyah, ${ }^{7}$ sistem pembangunan dengan sistem al-maqâșid diarahkan untuk membangun manusia pada level individu, masyarakat, berbangsa atau negara, serta internasional. Artinya, proses pembelajaran dalam hubungan intersubyektifitas pada masing-masing level tersebut dalam kesatuan yang utuh. Pembangunan tidak akan membawa pada taraf kesejahteraan yang diidealkan manakala salah satu dari komponen tersebut mengalami penyimpangan (deviasi). Seorang anak yang terdidik secara baik dalam lingkuangan keluarga, belum tentu menjadi baik manakala tatanan masyarakat di sekitarnya rusak. Sebaliknya, masyarakat madani tidak akan terwujud manakala individu yang ada pada setiap keluarga tidak baik. Begitu seterusnya.

Lalu, bagaimanakah pola relasi ideal yang dapat mewujudkan maslahah sebagai emergence properties yang diharapkan? Kita dapat merujuk pada surat Fâtịir [35] : 32. Ayat ini, pada dasarnya menjelaskan bagaimana sikap manusia terhadap al-Qur'an sebagai kitab yang menentukan derajat manusia. Artinya, relasi manusia dengan al-Qur'an mencerminkan pola hubungannya dengan sesama manusia dan alam semesta. Pada ayat ini, ada tiga relasi yang dijelaskan, yaitu: zôlimun li nafsihi (menganiaya diri mereka sendiri), muqtașid (posisi tengah), dan sâbiqun bi al-khairât (lebih dahulu berbuat kebaikan). ${ }^{8}$

7 Jamal al-Dîn Ațiyah, Nahwa Taf'îl Maqâş̧id al-Syarî'ah, (Amman: al-Ma'had al-'âlamî li al-Fikr al-Islâmî, 1999M).

8 Para ahli tafsir secara tradisional menjelaskan tingkatan kualitas muslim tersebut berdasarkan volume amal perbuatan sehari-hari. Pada tingkatan pertama zôlimun linafsihi yaitu mereka yang menganiaya diri sendiri dengan melaksanakan perintah, tetapi juga melanggar larangan agama sekaligus, kedua muqtașid yaitu melakukan perbuatan kebajikan dan meninggalkan perbuatan kemungkaran tapi terkadang terjebak pada kemaksiatan, sedangkan ketiga sâbiqun bi al-khairât adalah mereka melakukan perbuatan terpuji (al-ma'rufât) secara konsisten dan tidak mau menyentuh amalan tercela (al-munkarât) meskipun kecil. Mustafa al-Maragi menjelaskan kualitas muslim tersebut dengan uraian yang sedikit berbeda: Zôlimun linafsihi yaitu mereka yang melakukan amalan kemaksiatan lebih besar dari 
Relasi pertama, (zôlimun li nafsihi) adalah relasi yang memposisikan alQur'an sebagai objek untuk melegalkan setiap tindak-tanduk manusia atau bahkan mengabaikan al-Qur'an sama sekali. Pola relasi ini merupakan relasi individualistik yang sasarannya adalah maksimalisasi kepuasan dan minimalisasi resiko dengan mengabaikan atau masa bodoh terhadap orang lain. Relasi kedua (muqtașid), yaitu mereka yang membaca al-Qur'an namun tidak menjadikannya sebagai pedoman untuk kemajuan umat. Al-Qur'an dibaca sebatas ritual untuk meningkatkan kesalehan individual. Sekalipun berbicara mengenai umat, namun bersifat ekslusif dan cenderung sporadis. Adapun pola relasi ketiga, (sâbiqun bi al-khairât), yaitu mereka yang mempelajari al-Qur'an dan menjadikannya sebagai pedoman untuk memajukan peradaban manusia dan berlomba-lomba melakukan kebaikan dengan pedoman tersebut. Pengembangan sains, teknologi, lingkungan hidup, sosial, budaya, dan lain sebagainya merupakan hasil dari proses pembelajaran manusia yang ia peroleh dengan memahami al-Qur'an sebagai ayat al-qauliyah dan alam sebagai ayat al-kauniyah. Relasi yang diperlihatkan adalah dalam rangka menunjukkan al-Qur'an sebagai rahmatan lil 'âlamîn, karena inti dari sifat Allah swt. adalah rahmah atau memberikan kebaikan yang nyata (Q.S. al-An'am : 12).

Berdasarkan pola relasi tersbut, sebagai bagian dari proses pembelajaran, pembangunan tidak dapat terwujud dengan semestinya manakala arah dan tujuan pembangunan adalah untuk meningkatkan pertumbuhan ekonomi atau untuk meningkatkan indeks pembangunan manusia sebagaimana selama ini dielu-elukan. Sebab, pola relasi yang dibangunan adalah relasi persaingan untuk meningkatkan pertumbuhan pada setiap indikator ekonomi. Terlebih, teori pembangunan semacam ini telah dikritik oleh para ekonom sendiri seperti Joseph Stiglitz, Amartya Sen, Umer Chapra, Abbas Mirakhor, Hossein Askari, dan lain sebagainya. Tegasnya, indikator pertumbuhan ekonomi tidak menjamin terciptanya kesejahteraan, kemakmuran, dan kedamaian yang merata di suatu negara.

Karl Marx jauh hari telah mengingatkan bahwa kapitalisme akan membuat manusia teralienasi dari kehidupan atau hakikatnya sendiri dan pada ujung-

amalan kebajikan dengan selalu menuruti hawanafsunya, muqtașid adalah orang yang seimbang antara amalan kebaikan dan kejahatannya, sedangkan sâbiqun bi al-khairât adalah orang yang terus menerus mencari ganjaran Allah dengan melakukan amal-amal kebaikan. 
nya menjadi agama sekedar penghilang rasa sakit atau candu. Fenomena ini agaknya sangat beralasan. Dalam laporan Happy Planet Index tidak satu pun negara-negara maju disebut sebagai kategori negara yang dapat memberikan kebahagiaan. Pekerjaan telah membuat manusia larut dalam rutinitas dan persaingan untuk mencapai target-target yang telah ditentukan perusahaan. Tujuan dari target tersebut adalah untuk meningkatkan keuntungan perusahaan. Pada titik ini, sesungguhnya telah terjadi penyimpangan yang sangat jauh dari sistem pembangunan yang diharapkan yaitu dari memanusiakan manusia (maqâssid) menjadi manusia sebagai mesin penghasil keuntungan. Betapa banyak kita menyaksikan, khusus kaum wanita, dijadikan objek untuk menarik perhatian konsumen dengan identitas pekerjaan sebagai "SPG-Sales Promotion Girl" yang seringkali dijadikan objek ekploitasi seksual. Ironisnya, teori mana yang menjelaskan bahwa pola relasi demikian sebagai penyimpangan? Alihalih, yang terjadi justeru 'pembedakan' terhadap wajah dari sistem ekonomi yang telah rusak.

Sebagai sebuah sistem, al-maqâsid memerlukan konsep yang menggambarkan perilaku semua komponen. Konsep ini dalam perspektif teori kompleksitas, dikenal dengan limited degree of freedom, maximum degree of freedom, dan required degree of freedom. Yang pertama mengacu pada perilaku komponen (individu, masyarakat, dst) sistem yang tidak cukup dinamis dan tergerak untuk melahirkan sinkronisasi. Sebaliknya, maximum degree of freedom adalah kondisi di mana tiap-tiap komponen terlalu liar sehingga tidak akan melahirkan polapola relasi yang sama dan tidak berubah. Kedua perilaku dari relasi komponen ini sama-sama tidak menciptakan kondisi yang diperlukan (required degree of freedom). Untuk itu, maka diperlukanlah expanding the degree of freedom sebagai konsep yang digunakan untuk menghasilkan pola relasi yang menjamin keutuhan sistem, serta tidak dimaksudkan untuk melahirkan maximum degree of freedom. ${ }^{9}$

Berdasarkan konsep-konsep di atas, maka kita dapat melakukan pembacaan ulang terhadap level maquașid, yaitu darûrîyah, hâjjîyah, dan tahsînîyah . Level darûrîyah dapat dikategorikan sebagai konsep minimum degree of freedom, level hâjîyah, sebagai required degree of freedom, dan level tahsînîyah sebagai maximum degree of freedom. Artinya, relasi dan keutuhan komponen dalam sistem

\footnotetext{
9 Muazd, Anatomi Sistem, hal. 19.
} 
pembangunan berbasis maqâșid sangat ditentukan pada perilaku masing-masing komponen. Dapat dimaknai, kondisi darûrîyah, mencerminkan kondisi pada tiap-tiap komponen bergerak dengan sangat tidak dinamis, sehingga melahirkan banyak ketimpangan. Sebaliknya, kondisi tahsînîyah mencerminkan gerak komponen yang terlalu liar, sehingga tidak berdampak positif terhadap dinamika relasi antar komponen, yaitu bahwa manusia bukanlah terbatas sebagai makhluk materi yang berada pada alam kehidupan. Lebih dari itu, ia memiliki kesadaran bahkan manusia adalah makhluk spiritual yang memiliki pengalaman di dunia materi. Berdasarkan perspektif ini, pembangunan tidak lagi diarahkan pada upaya penumpukan materi, eksploitasi alam, yang pada ujungnya menimbulkan berbagai bentuk ketimpangan, kerusakan, ketidak-teraturan. Lebih jauh, menciptakan dehumanisasi terhadap manusia. Di sini, dapat dipahami bahwa komponen dasar bagi pembangunan adalah manusia itu sendiri. Akan tetapi, ia tidak dilihat sebatas makluk individu karena sikap ini melahirkan sikap individualis-utilitarianism.

\section{E. Sistem Strategi Maqashid}

Pemanfaatan sumber daya untuk kepentingan mensejahterakan masyarakat tidak dapat dilakukan hanya dengan mengedepankan kekuatan pasar (kapitalisme) atau perencanaan terpusat (sosialisme).${ }^{10}$ Sebaliknya, realokasi sumber daya yang ada dalam bingkai maqashid mendorong terbentuknya hubungan intersubyektif yang tidak lagi berdasarkan pada semangat kompetisi, survival of the fittes, melainkan dilandasi semangat nilai-nilai persaudaraan, kesetaraan, kasih dan sayang. Akan tetapi, pada diri manusia juga terdapat potensi keburukan (fujur) sehingga memungkinkan mereka bertindak eksploitatif, merusak, dan mengacaukan keharmonisan sistem. Untuk itu, perlu upaya restrukturisasi yang mendorong agar terbentuknya:
a) Tranformasi faktor manusia dalam pembangunan untuk memung- kinkan memainkan peran yang aktif dan konstruktif.
b) Mengurangi pemusatan dalam kepemilikan alat-alat produksi.
c) Menghilangkan atau meminimalkan semua konsumsi yang sia-sia dan

10 Lihat Fayiz Ibn Ibrahim al-Habib, Isti'radh li al-Kitabat al-Mu'sharah fi al-Tanmiya dalam: , Isham al-Fikr al-Islami fi al-Iqtishad al-Mu'ashir yang dipublikasikan oleh al-Ma'had al-'Alami li al-Fikr al-Islami, 1412 H/1992 M, hal. 385-425. 
tidak perlu pada tingkat pribadi dan masyarakat agar sumber tersebut dapat diberikan tujuan-tujuan sosial.

d) Melakukan reorganisasi investasi guna memungkinkan sistem produksi berbasis kebutuhan, dan

e) Melakukan reformasi sistem keuangan sesuai dengan ajaran Islam guna sebagai tindakan aktif untuk mewujudkan maqashid.

Restrukturisasi seperti itu tidak mungkin tanpa peran yang aktif dan positif dari pemerintah dalam bidang ekonomi. Peran ini tidak dalam bentuk totaliarisme seperti yang terjadi pada sistem sosialisme. Peran ini lebih kepada peran komplementer yang harus dimainkan, tidak melalui pengawasan yang berlebihan, pelanggaran yang tidak semestinya terhadap kebebasan individu dan abolisi terhadap hak-hak milik. Sebaliknya peran itu berupa penciptaan lingkungan yang sehat dan pembangunan lembaga-lembaga tepat fungsi. Keempat pendekatan dimensional dalam Islam (ada mekanisme filter nilai-nilai, ada motivasi individu, ada restrukturisasi sosial ekonomi, dan ada peran positif pemerintah) harus menjadi lebih efektif dalam menjamin kehidupan yang lebih baik bagi semua manusia.

Bertolak belakang dari hal ini, maka pemerintahan Indonesia yang miskin secara umum di dalamnya menganut faham sekuler, terkait dengan warisan kolonial dan kebijakan konvensional. Negara ini boleh dikatakan tidak memiliki filosofi pembangunan yang konsisten untuk mewujudkan maqashid. Maka, kebijakan-pemerintah tidak punya arah yang jelas dan telah berpaling kepada sosialisme dan berusaha bebas kontrol serta kebebasan yang sangat digemari dalam pembangunan pada tiga era ini yaitu orde lama, orde baru dan orde reformasi. Tidak adanya arah yang jelas, diikuti dengan fluktuasi dan tidak konsisten dalam kebijakan-kebijakan, telah mengakibatkan ketidakpastian dan menyebabkan bahaya yang luar biasa terhadap proses pembangunan. Apapun pembangunan yang berhasil dijalankan kenyataanya mengakibatkan biaya tinggi berkaitan dengan ketimpangan makroekonomi, ketidaksemibangan yang meningkat terhadap pendapatan, kesejahteraan, dan tensi sosial.

Langkah-langkah kebijakan-kebijakan yang dianjurkan di bawah ini umumnya dikenal dalam literatur pembangunan. Originalitas tidak ada pada langkah-langkah tersebut. Apa yang penting adalah pendekatan terpadu dalam kerangka pandangan Islam dan strategi untuk mewujudkan maqashid untuk 
kepentingan Indonesia tanpa meletakkan tekanan yang berlebihan atas sumber-sumber terbatas yang ada.

\section{F. Faktor Manusia: Motivasi dan Kemampuan}

Mengalokasi sumber-sumber daya secara efisien dan sesuai dan menghilangkan ketimpangan-ketimpangan dimulai dengan meningkatkan kualitas pada diri masyarakat itu sendiri, yakni kualitas yang memungkinkan mereka dapat memenuhi kebutuhan sendiri dan kualitas yang dapat menjamin kesejahteraan seluruh manusia. Mereka harus mau dan mampu menunjukkan kemampuan terbaiknya dengan bekerja keras dan efisien, dengan integritas kesadaran dan disiplin dan harus juga mau mengorbankan kesenagan diri sendiri guna menghilangkan hambatan-hambatan dalam pembangunan. Mereka juga harus merubah perilaku konsumsi, deposito dan investasi berkaitan dengan apa yang diperlukan untuk mewujudkan maqashid. Ini membutuhkan motivasi dan kemampuan yang sesuai dan memadai.

\section{Motivasi ${ }^{11}$}

Jika masing-masing manusia tidak terdorong secara baik, tidak ada sistem dapat merealisasikan baik efisiensi dalam penggunaan sumber daya atau ekuitas dalam distribusinya. Lingkungan sosial ekonomi umat Islam di Indonesia saat ini terlihat secara jelas belum adil yakni belum mampu mendorong orang untuk menunjukkan kemampuan terbaiknya baik berkaitan dengan kepentingan diri sendiri maupun kepentingan masyarakat. Oleh karena itu, penting mengadopsi kebijakan-kebiajakan yang akan membantu menjamin kedua hal ini. Untuk membuat orang bekerja untuk pemenuhan kepentingan pribadi, mereka harus memiliki jaminan bahwa pemenuhan kebutuhannya tersebut harus dicapai dengan kerja keras, kreatifitas dan kontribusi untuk output. Dengan kata lain, harus ada keadilan sosial ekonomi-hubungan yang saling berkaitan antara kuantitas dan kualitas dari output dan penghargaan.

Jika individu tersebut, terlepas dari apakah mereka pekerja, penabung, in-

11 Konsep tersebut juga lihat Economic Development in Muslim Countries: A Strategy for Development in the Light of Islamic Teachings, by M. Umer Chapra, hal.475-534 salah satu dari sejumlah makalah dalam: Isham al-Fikr al-Islami fi al-Iqtishad al-Mu'ashir yang dipublikasikan oleh al-Ma'had al-'Alami li al-Fikr al-Islami, 1412 H/1992 M. 
vestor, atau eksportir, tidak mampu membagi secara wajar hasil dari kontribusi output melalui penghargaan resiprokal, mereka cenderung menjadi apatis dan inisiatif, dorongan dan efisiensi sangat rendah. Dalam praktik di Indonesia, penghargaan materi tidak pernah dapat adil karena adanya bias-bias serta kurangnya realisme dalam kebijakan-kebijakan resmi, dan konsentrasi kekayaan dan kekuatan pada segelintir tangan yang terjadi baik di daerah perkotaan ataupun di pedesaan. Kurangnya realisme telah mengakibatkan distorsi terhadap harga primer dimana secara tidak sadar mengakibatkan penurunan pendapatan petani-petani dan pengusaha-pengusaha kecil serta para pekerja. Ini juga mengakibatkan berkurangnya pemenuhan atas kebutuhan dan terciptanya alokasi yang tidak tepat terhadap sumber-sumber daya yang tidak sesuai dengan pemenuhan kebutuhan itu. Pemusatan kekayaan dan kekuatan, juga tidak terlepas dari kebijakan-kebijakan resmi dan juga tidak terlepas dari sistem ekonomi eksploitatif yang masih berlangsung terus, telah membatasi kompetisi, menyebarkan kolusi dan menciptakan iklim kondusif terhadap kemiskinan massa. Hal ini telah menurunkan kemauan dan kemampuan untuk menunjukkan kerja terbaik mereka.

Upah riil minimum dalam masyarakat Islam, hendaknya bisa mencapai taraf dimana mereka dapat memenuhi kebutuhan-kebutuhan pokok diri dan keluarganya menurut kelaziman yang berlaku. ${ }^{12}$ Faktanya, di sebagian besar negara Islam upah para buruh sangat kecil, meskipun mereka bekerja 10-14 jam. ${ }^{13}$ Mereka tidak mampu memenuhi kebutuhan pokok diri dan keluarganya. Hal ini karena eksploitasi yang berasal dari ketidaktepatan kebijakan-kebijakan pemerintah, konsentrasi kekayaan dan kekuatan, kemiskinan dan kurangnya fasilitas pelatihan bagi tenaga kerja dan anak-anak mereka. Jika situasi ini tidak diluruskan, tidaklah mungkin untuk mendorong pekerja untuk bekerja secara sadar dan efisien. ${ }^{14}$

12 Asmuni Mth, Perburuhan Prespektif Islam, Jurnal al-Mawarid Fakultas Syariah Universitas Islam Indonesia, Edisi I, 1994.

13 Sehubungan dengan jam kerja diperlukan penelitian serius tentang jumlah jam, jumlah hari para pekerja di Indonesia bekerja dalam satu tahun, dikhawatirkan jika para pekerja hanya mendapat hari kerja dalam satu tahun hanya 100 hari dengan upah minimum yang tidak sesuai dengan maqashid adalah sangat sulit untuk mengatakan bahwa mereka terbebaskan dari kemiskinan.

؛' عبد الله عبد العزيز عابد (كلية التجارة جامعة الأزهر) ، مفهوم الحاجات في الإسلام وأثره على النمو الاقتصادي ، ص VI. 14 
Tidak bisa dinafikan, upah menjadi faktor utama yang memotivasi seseorang bekerja, di samping juga ada faktor lain, baik yang bersifat teologis maupun psikologis. Sebagaimana telah disebutkan, persoalan upah menjadi sarana eksploitasi terhadap manusia dan menjadi sarana untuk mengeksploitasi alam. Akan tetapi, sekalipun sangat penting, namun penetapan upah selalu menjadi masalah yang terus menghantui di sebagian besar negara berkembang. Hal ini disebabkan oleh telah terjadinya pertarungan dua kepentingan, dan alasan "kompetisi" menjadikan upaya menciptakan upah yang adil seolah sulit dilakukan. Sebutlah di Indonesia. Banyak pekerja, baik laki-laki maupun perempuan yang bekerja di perusahan besar, digaji di bawah standar hidup layak. Mereka dihadapkan pada pilihan sulit. Menuntut kenaikan upah harus diancam PHK, sedang terus bekerja menjadikan mereka manusia yang nilainya lebih murah dari pada mesin-mesin produksi.

\section{Kemampuan}

Walaupun keadilan sosial ekonomi dan kesadaran moral adalah penting untuk mendorong masyarakat, keduanya tidak cukup untuk mewujudkan 'efisiensi dan equitas'. Dua orang mungkin saja sama-sama memiliki motivasi, tetapi mereka tidak mampu menyumbangkan secara seimbang untuk merealisasikan maqashid. Perbedaannya berada pada kemampuan yang tidak hanya sejak lahir tetapi juga dipelajari, sebagian melalui pendidikan dan pelatihan dan sebagian lagi melalui akses keuangan. Perluasan fasilitas pendidikan dan pelatihan dan akses orang miskin kepada faktor keuangan juga sangat penting. Pendidikan dan pelatihan dapat meningkatkan kualitas manusia, keadilan sosial ekonomi yang lebih besar dan pertumbuhan yang lebih cepat. Hal inilah yang terlihat sekarang ini diseluruh belahan negara di dunia. Pendidikan membuka pintu kesempatan serta pendidikan pula yang bisa membuat seseorang dengan yang orang lain memiliki persamaan. Akan tetapi, pemerintahan negara-negara Islam telah mengabaikan sektor penting dalam alokasi sumbersumber daya ini. Bahkan belum seluruh penduduk di negara-negara Islam bisa membaca (melek huruf), dimana hal ini merupakan langkah pertama dalam pendidikan. Pengabaian seperti itu berlangsung lama tanpa merusak struktur masyarakat Islam. 
Penekanan utama dari pendidikan adalah untuk menciptakan manusia Muslim yang 'baik'. Dalam perspektif sistem maqashid, keberadaan manusia sebagai khalifah adalah mengemban tugas pembelajaran yang berkelanjutan. Manusia dituntut untuk terus belajar tanpa mengenal usia, tempat, waktu, dan lain sebagainya. Tujuannya adalah agar terbentuknya pola relasi yang seimbang dan harmonis. Pola relasi ini dibangun berdasarkan kemampuan intelektual, skill, dan kreatifitas untuk memanfaatkan sumber daya alam sehingga menghasilkan produk yang dapat mewujudkan kesejahteraan bersama.

\section{G. Reformasi Pertanahan dan Pembangunan Pedesaan}

Tanah merupakan sumber daya yang sangat fital dan sejarah mencatat berbagai bentuk peperangan di dunia ini disebabkan oleh adanya keinginan menguasai tanah dan segala sumber daya yang ada di dalam dan di atasnya. Indonesia sebagai negara tropis memiliki tanah yang subur dan menyimpan banyak sumber energi yang dibutuhkan untuk berbagai kepentingan umat manusia. Akan tetapi, tata kelola tanah di negeri ini, sejak dahulu kala hingga saat ini masih menyimpan banyak permasalahan. Alih-alih, beberapa peraturan justeru membuka peluang sebebas-bebasnya bagi pihak asing untuk menguasi tanah dan sumber daya yang melekat padanya. Sebutlah misalnya UU migas, agraria, dan lain sebagainya.

Sejumlah kecil tuan tanah mengawasi sebagian besar alur tanah di daerah pedesaan dan bagian penting dari penduduk yang bertani merupakan mereka yang tidak memiliki tanah atau memiliki tanah yang tidak bernilai ekonomis. Hal ini menimbulkan eksploitasi oleh tuan-tuan tanah dan rentenir, serta hal ini pula merupakan salah satu sumber penyebab ketimpangan ekonomi yang berlanjut, dan ketiadaan proses demokrasi. Kemiskinan dari para petani penggarap dan buruh-buruh pedesaan mencegah mereka mengadopsi teknik-teknik bertani yang lebih baik, maka melanggengkan mereka kedalam kemiskinan dan degradasi moral yang permanen. Hal ini juga membunuh insentif dari penduduk pedesaan tersebut untuk menunjukkan yang terbaik dan menciptakan karaketeristik-karakteristik berupa malas, tidak jujur, dan apatis. Ini juga mendorong penduduk tersebut pindah ke kota untuk mencari pekerjaan. Disana juga mereka berada pada kondisi hidup yang tidak sehat dan jauh dari mereka-mereka yang disayangi. Kontrol sosial menurun dan, disertai de- 
ngan upah yang rendah dan frustrasi lainnya, mengakibatkan meningkatnya kejahatan dan gangguan-gangguan sosial lainnya.

Tidaklah mungkin untuk mengubah keadaan seperti ini tanpa melakukan reformasi pertanahan yang merupakan langkah pertama bagi semua kebiajakan ekonomi yang bertujuan untuk merealisasikan maqashid. Akan tetapi reformasi pertanahan berkait dengan langkah pemegang tanah dan istilah kepemilikan. Jika kedua hal ini tidak diselesaikan sesuai dengan tuntutan keadilan sosial dan ekonomi, sangatlah sulit untuk melakukan tindakan yang berarti dalam mewujudkan maqashid.

Jika tanah telah diperoleh dengan cara-cara yang adil dan diolah baik oleh pemilik sendiri atau disewakan kepada petani penggarap dalam 'arti yang 'sah', dan jika sistem Islam tentang warisan telah dilaksanakan dengan baik, kepemilikan tanah tersebut tidak akan lagi terkonsentarsi pada segelintir keluarga/orang saja. Akan tetapi karena tanah tersebut diperoleh dengan cara-cara yang tidak adil selama berabad-abad dan hukum Islam tentang warisan telah lama diabaikan, kepemilikan atas tanah menjadi tidak merata, mengakibatkan sebagian besar penduduk pedesaan ${ }^{15}$ mengalami kemiskinan dan penderitaan. Karena adanya situasi yang tidak adil ini, maka penting sekali membentuk batasan ukuran maksimum kepemilikan lahan dan mendistribusikan kelebihannya kepada para petani yang tidak memiliki lahan.

Hukum syari'ah tidak menunjukkan rancangan batasan tentang kekayaan pribadi dalam sistuasi yang normal. ${ }^{16}$ Meskipun demikian, Syari'ah tegas memberikan wewenang kepada negara untuk mengambil semua langkah-langkah yang dianggap perlu untuk mewujudkan maqashid. Hal ini karena langkahlangkah tersebut tidak secara khusus dilarang oleh Syari'ah. ${ }^{17}$ Karena kepemilikan lahan terpusat pada segelintir orang saja, eksploitasi, kemiskinan dan pemanfaatan yang tidak efisien lahan dan buruh akan berlanjut, dan tujuan untuk mewujudkan distribusi sebaran yang adil atas kekayaan masih belum menentu

\footnotetext{
• ع عمد علي السلوس ، ملكية الأفراد للأرض ومنافعها في الإسلام ، بحث منشور في المؤتمر الأول بلمع البحوث الإسلامية ، الأزهر 15 (

"جميل الشرقاوي ، قيود الملكية للمصلحة العامة قي الشريعة الإسلامية ، في بحلة الحقوق والشريعة ، كلية الحقوق والشريعة جامعة 16

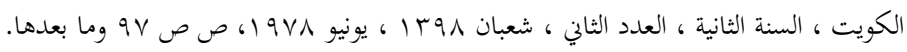

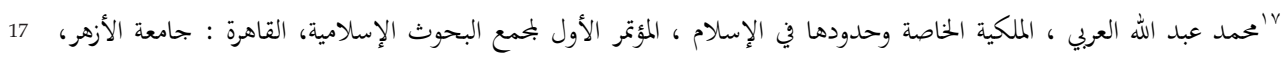


sepanjang kekuatan tuan tanah yang monopolistik dan monosomatic tidak diputus dengan menentukan batasan yang jelas atas ukuran maksimum tanah yang bisa dimiliki oleh satu keluarga. Sekalipun besarnya penduduk pedesaan sekarang dibandingkan dengan jumlah keseluruhan lahan yang tersedia mengharuskan adopsi terhadap satu tindakan mewujudkan maqashid. Sesuai dengan hal ini, sejumlah sarjana yang terkenal berpendapat setuju terhadap pembatasan untuk mengembalikan keseimbangan ekuitas dalam kepemilikian dan untuk menjaga kepentingan sosial. ${ }^{18}$ Karena Syari'ah menuntut pembayaran terhadap konpensasi yang pantas kepada pemilik yang sah, lahan tersebut tidak harus diberikan kepada para petani secara bebas. Akan lebih baik jika mereka membayar dengan harga yang fair, yakni nilai keseluruhan yang diwujudkan oleh pemerintah secara bertahap beberapa tahun sesuai dengan penghasilan petani tersebut, serta sebagian digunakan untuk kompensasi para pemilik yang 'sah' (dan hanya pemilik yang sah) dan sebagian lagi untuk memenuhi biaya pembanguan pedesaan desa tersebut.

Lebih jauh, untuk menurunkan ukuran kepemilikan lahan, juga penting untuk mereformasi istilah-istilah sewa menyewa. Walaupun tujuan membangun keadilan antara tuan tanah dan penyewa masih diperdebatkan oleh para ulama fiqih disemua aliran yurisprudensi Islam, hakikat dari sewa menyewa lahan telah menjadi satu isu yang sangat kontroversial dalam literatur fiqih. Sebagian kecil ahli hukum tidak membolehkan bagi hasil panen atau sewa meyewa yang tetap dan menuntut bahwa pemilik lahan harus mengolah sendiri sesuai kemampuannya dan memberikan pemanfaatan keseimbangan pada seseorang yang dapat melakukan hal ini. Sebagian besar lainnya yang membolehkan bagi hasil panen tetapi melarang sewa-menyewa tetap. Penolakannya adalah bahwa meskipun Nabi Muhammad SAW. tidak melakukan kedua hal itu, namun kemudian beliau membolehkan bagi hasil panen, dan ini telah dilakukan oleh para pengikut beliau turun temurun. Akan tetapi mayoritas ahli hukum membolehkan kedua hal itu, ini sejalan dengan diperbolehkannya mudarabah dan penyewaan dalam Syari' ah. Alasannya adalah bahwa kemiskinan dari sebagian besar umat Islam dalam periode Madinah telah membuat Nabi tidak mendorong sistem kedua sistem ini. Akan tetapi, kemudian hari ketika

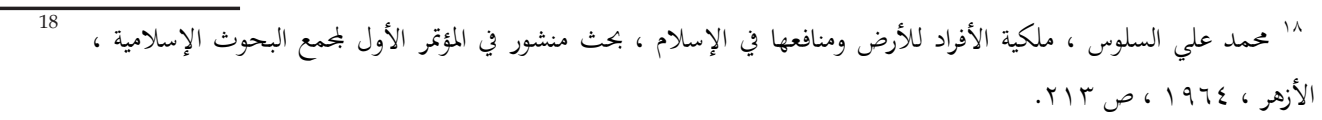


kondisi ekonomi umat Islam membaik, beliau membolehkan bagi hasil panen dan sewa menyewa tetap, dan tidak hanya bagi hasil panen saja seperti pendapat sebagian ahli hukum yang kedua. Meskipun demikian, Ibnu Taimiyah dan sejumlah ahli hukum lainnya menganggap bahwa sewa menyewa tetap itu hukumnya makruh. ${ }^{19}$ Menurut mereka bagi hasil panen itu leih baik sebab lebih dekat kepada keadilan; bagi hasil ini menuntut pemilik lahan dan penyewa untuk membagi hasil sekaligus risiko pertanian, berbeda dengan sewa menyewa tetap, yang menjamin tuan tanah untung tetap meskipun penyewa memperoleh hasil ataupun tidak ada hasilnya.

Karena penggarap dan petani yang tidak memiliki lahan lemah dan tidak berdaya dan mungkin masih terus demikian untuk beberapa waktu meskipun pelaksanaan terhadap pembatasan ukuran kepemilikan lahan tersebut, sewa meyewa tetap lahan mungkin dapat menjadi penyebab ketidakadilan dan kemiskinan jika output masih terus tidak menentu. Oleh karena itu akan lebih menyenangkan bagi pemerintah Islam untuk membuat bagi hasil panen sebagai dasar umum dari sewa lahan dan berusaha untuk membagi secara adil hasil antara pemilik tanah dan penggarap. Hal ini harus berlanjut setidaknya paling tidak sampai dasar kekuatan di wilayah pedesaan telah diperluas dan sisi eksploitasi dari keluarga pemilik lahan telah dikurangi secara substansial.

Pentingnya reformasi pertanahan guna menciptakan iklim yang demokratis dan egalitarian dimaksudkan agar terbentuknya desa-desa yang memiliki inisiatif dan kemandirian untuk meningkatkan hasil pertaniannya. Di samping itu, mereka juga dapat membentuk usaha kecil dan menengah pada sektorsektor lain, seperti dengan menghasilan produk-produk ekonomi kreatif dan kewirausahaan. Pada ujungnya, reformasi pertanahan dapat meningkatkan kualitas hidup masyarakat desa, sehingga dapat mengurangi urbanisasi, pengangguran, kemsikinan, dan kriminalitas di kota.

\section{H. Pengembangan Usaha-Usaha Mikro dan Kecil}

Setelah melakukan reformasi pertanahan, langkah selanjutnya adalah mendorong terciptanya berbagai bentuk usaha mikro dan kecil (UMK). Di samping itu, adanya UMK diharapkan mampu menurunkan konsentrasi kekayaan

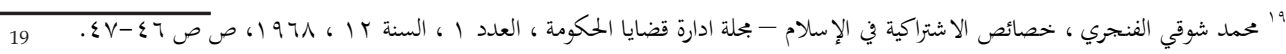


dan modal di kawasan perkotaan saja. Lebih dari itu, UMK merupakan fondasi ekonomi yang sangat kuat yang dapat melindungi suatu negara pada saat mengalami krisis atau depresi ekonomi. Indonesia, misalnya. Banyaknya UMK telah menyelamatkan Indonesia dari kondisi chaos akibat krisis moneter. Namun sayang, sekalipun 99\% bisnis di Indonesia masuk ke dalam kategori UMK, namun perhatian pemerintah dirasakan masih sangat kurang.

Untuk itu, saat ini, Bank Indonesia tengah berupaya memperkuat sektor UMKM sebagai konsekuensi dari kebijakan moneter yang menuntut stabilitas ekonomi tetap terjaga. BI telah membuat beberapa klaster UMKM dan menyediakan data perkembangannya, sebagaimana dapat dilihat di website resmi BI. Kebijakan ini juga diikuti dengan tengah dicanangkannya sistem branchless atau sistem perbankan tanpa kantor. Tujuan utamanya adalah agar bisa menjangkau kebutuhan permodalan masyarakat di daerah atau desa-desa kecil. Di sisi lain, data menunjukkan bahwa 99.9\% perekonomian Indonesia ditopang oleh sektor UMKM, bukan UB (usaha besar).

Tabel 1.1

Perkembangan UMKM dan UB

\begin{tabular}{|c|l|r|r|r|r|}
\hline \multirow{2}{*}{ No } & \multirow{2}{*}{ Unit Usaha } & \multicolumn{2}{|c|}{$\mathbf{2 0 1 0}$} & \multicolumn{2}{c|}{ 2011 } \\
\cline { 3 - 6 } & & Jumlah & Pangsa (\%) & \multicolumn{1}{c|}{ Jumlah } & Pangsa (\%) \\
\hline 1 & A. UMKM & 53.823 .732 & 99,99 & 55.206 .444 & 99,99 \\
\hline & Usaha Mikro (UMi) & 53.207 .500 & 98,85 & 54.595 .969 & 99 \\
\hline & Usaha Kecil (UK) & 537.601 & 1,07 & 602.195 & 1,09 \\
\hline & Usaha Menengah (UM) & 42.631 & 0,08 & 44.280 & 0,08 \\
\hline 2 & B. Usaha Besar & 4.838 & 0,01 & 4.952 & 0,01 \\
\hline
\end{tabular}

Sumber : www.depkop.go.id (diolah)

Menurut Tulus Tambunan, Usaha Mikro, Kecil dan Menengah (UMKM) memainkan peran penting di dalam pembangunan dan pertumbuhan ekonomi, tidak hnya di negara-negara sedang berkembang, tetapi juga di negara-negara maju. ${ }^{20}$ Artinya, melemahnya pertumbuhan UMKM merupakan indikasi kerapuhan ekonomi suatu negara. Pada titik ini, posisi Indonesia sebagai negara sedang berkembang memiliki kekuatan sangat besar pada sektor UMKM. Tipe piramida penduduk Indonesa yang ekspansif di mana sebagian besar penduduk berada pada kelompok umur muda atau usia produktif menuntut terse-

20 Tulus Tambunan, Usaha Mikro Kecil dan Menengah di Indonesia: Isu-isu Penting, (Jakarta : LP3ES, 2012), hal., 1 
dianya lapangan kerja yang menyerap banyak tenaga kerja. Lebih dari itu, angka kemiskinan dan pengangguran Indonesia masih sangat tinggi. Berdasarkan data BPS, hingga September 2012 tercatat 11,66\% atau setara dengan 28.59 juta. Adapun jumlah pengangguran terbuka hingga Agustus 2012 sebanyak 6,14\% atau sekitar 7.244.956. ${ }^{21}$

\section{Kesimpulan}

Pembangunan ekonomi dengan keadilan sosial ekonomi, di mana Islam mensucikannya, tidak dapat dicapai dalam batasan kemampuan sumber dari negara-negara Islam jika tidak terdapat satu perubahan revolusioner dalam hal prioritas dan satu mekanisme motivasi guna membawa masyarakat merubah perilaku kerja, konsusmsi, penghematan dan investasi sesuai dengan prioritas ini. Kaum sekuler, nilai netral dan perspektif keduniaan baik kapitalis dan sosialis, dimana negara-negara Islam sekarang sedang menerapkan, tidak dapat membantu baik dalam membentuk prioritas yang benar atau dalam mendorong orang untuk merestrukturisasi kliam-klaim atas sumber-sumber sesuai dengan prioritas ini. Jika masyarkat kapitalis dan sosialis telah gagal mencapai tujuan sosial ekonomi yang ditetapkan, mereka tidak dapat berfungsi sebagai model negara-negara Islam dengan sumber-sumber yang relatif semakin langka.

Oleh karena itu Islam telah berpindah dari kedua sistem tersebut untuk mejamin realisasi efisiensi dan juga ekuitas. Walaupun Islam telah mengenal kontribusi dimana motif keuntungan, properti swasta dan proses pengambilan keputusan yang terpusat dari sebuah ekonomi pasar dapat membuat efisiensi, namun Islam juga memperkenalkan cara unsur-unsur penting lain dalam sistem ekonominya guna mengaktualisasikan keadilan. Oleh karena itu, adanya ketimpangan eksternal dan makroekonomi diikuti dengan ketidakpantasan dan tensi sosial politik yang masih ada di negara-negara Islam, hanya alternatif yang layak adalah meng-Islamkan perekonomian tersebut. Hal ini tidak hanya akan mengurangi ketimpangan tetapi juga membuat kontribusi nyata pada harmonisasi sosial melalui aktualisasi maqashid. Konsep pertanggungjawaban kepada Allah akan berfungsi sebagai daya motivasi yang kuat.

21 Badan Pusat Statistik, Laporan Bulanan Data Sosial Ekonomi, Edisi 34, Maret 2013, (Jakarta : BPS, 2013). 
Konsep ini menjaga kepentingan pribadi dalam batasan kesejahteraan sosial, dan bersama dengan mekanisme filter terhadap nilai dan harga yang realistis, mengahsilkan kualitas dan kuantitas pengurangan klaim-klaim dimana realisasi maqashid memerlukannya.

\section{DAFTAR PUSTAKA}

Al-Quran al-karim

Abd al-Mannan, Muhammad, tt, Al-Iqtisâd al-Islâmi baina al-nazariyat wa al-tathbiq, (Al-Maktab al-ârabi al-hadis)

Abu Su'ud, Mahmud 1968, Khuthut ra'isiyyah fi al-Iqtisha`d al-Isla`miyy, Maktabat al-mana`r al-isla`miyyah, Kuwait.

Abu Zahrah, Muhammad, 1977, al-Milkiyah wa Nazariyat al-'Aqd, al-Qohirah, Dar al-Fikr al-'Arabi).

Affar, Muhammad Abdul Mun'im, 1985, al-Takhtith wa al-Tanmiyah fi al-Islam, (Jeddah : Dar al-bayan al-Arabi).

Afifi, Ahmad Mustafa , 1407 H/1986 M, Istismâr al-mâl fi al-Islâm, Maktabah Wahbah, $1424 \mathrm{H} / 2003 \mathrm{M}$.

Ahmad, Abdurrahman Yasri, 1985, Al-'Alaqât al-iqtisôdiyah baina al-buldân alislâmiyah wa dauruha fi al-tanmiyah al-iqtisôdiyah, (Jeddah: Dirâsât fi aliqtisôd al-islâmi, Markaz abhâs al-iqtisôd al-islami, Jami'ah al-malik Abdul Aziz).

Ațiyah, Jamal al-Dîn, Nahwa Taf'îl Maqâşid al-Syarî'ah, (Amman: al-Ma'had al'âlamî li al-Fikr al-Islâmî, 1999M).

Ahmad, Khursyid, 1985, Al-Tanmiyah al-iqtisôdiyah fi ithorin islamiyin, tarjamah Rafiq Al-misri, Majalah Abhâs al-iqtisôd al-islâmi, nomor 2, bagian 2.

Ajwah, Athif, 1983, Mafhum al-Tanmiyah al-Iqtisodiyah wa al-Fikr al-Iqtisodi al-Islami, dalam Majallah al-Iqtisod wa al-Idarah, (Jeddah: Markaz al-Buhus wa al-Tanmiyah, Jami'ah Malik Abdul Aziz), nomor 17, edisi Sya'ban 1403 H, Mei 1983.

Ali Al-Qirô, Muhammad bin 'Abid, 1412H/1992, Isti'râd li al-kitâbât al-mu'âsirah fi al-tanmiyah.

Alim, Yusuf Hamid, 1412 H/1991 M, al-Maqâsid al-'ammah li al-Syari'ah al-Islamiyah, Herndon, al-Ma'had al-'alami li al-Fikr al-Islami. 
Ansari, Javed, 1985, Ekonomi Islam antar Neoklasik dan Strukturalis: Laporan dari Islamabad dalam Islamisasi Ekonomi: suatu Sketsa Evaluasi dan Prospek Gerakan Perekonomian Islam, (Amrullah dkk., e.,) PLP2M, Yogyakarta.

Ibn 'Asyur, Muhammad Thohir, 1988, Maqasid al-Syari'ah al-Islamiah, Tunis: alSyarikah al-Tunisiah li al-tauzi',

Ba'li, Abdu al-Hamid Mahmud, 1421 H/2000, al-Istikhlâf wa al-Milkiyah,

Cahyo, Agus N., 2011, Tokoh-Tokoh Timur Tengah yang Diam-Diam Jadi Antek Amerika dan Sekutunya, , (Yogyakarta: DIVA Press,).

Chapra, M. Umer, Economic Development in Muslim Countries: A Strategy for Development in the Light of Islamic Teachings, , hal.475-534 salah satu dari sejumlah makalah dalam: Isham al-Fikr al-Islami fi al-Iqtishad al-Mu'ashir yang dipublikasikan oleh al-Ma'had al-'Alami li al-Fikr al-Islami, 1412 H/1992 M.

Dunya, Syauqi Ahmad, 1979, Al-Islâm wa al-tanmiyah al-iqtisôdiyah, (Kairo: Dar al-fikr al-'Arabi).

Dunya, 1984, Tamwil al-tanmiyah fi al-iqtisôd al-islami, (Beirut: Muassasah alrisalah). Bakhit. Ali Khidar, $1404 \mathrm{H}$, Al-Tamwil al-dakhil li al-tanmiyah al-iqtisadiyah dalam al-Islam, (Jeddah: Al-Dar al-Su'udiyah li al-Nasyr wa al-Tauzi')

Fanjari, Muhammad Syauqi Khosois al-Isytirokiyah fi al-Islam, Majallah Idarat Qodhoya al-Hukumah, al-'adad 1, al-sanah 12, 1968.

Fanjari, Al-Islam wa al-Musykilah al-Iqtisodiyah, (Maktabah al-Anglo al-Misriyah), hal. 81, dan Al-Mazhab al-Iqtisodi fi al-Islam, (Jeddah: Buhus Mukhtarah min al-Mu'tamar al'alami al-awwal li al-iqtisod al-islami, (Jeddah: Markaz abhas al-iqtisod al-islami).

Muadz, M. Husni, Anatomi Sistem Sosial Rekonstruksi Normalitas Relasi Intersubyektivitas dengan Pendekatan Sistem, (Mataram: Institut Pembelajaran Gelar Hidup [IPGHI], 2014).

Al-Fâsi, 'Allal al, Maqosid al-syari'ah al-Islamiyah wa makarimuha, Maroko Maktabah al-Wahdah al-Arabiyah, Al-Dar Al-Baidho'.

Al-Fâsi, al-Islâm wa mutatollabât al-tanmiyah fi mujtama' al-yaum,(Dahran: Multaqâ al-fikr al-islâmi, 1971). 
Hasry, Ahmad, as-Siyâsah al-Iqtisâdiyah wa an-Nuzum al-Maliyah fi al-Figh alIslami, Beirut: Dâr al-Kitâb al-'Arabi.

Hendrajit Dkk, 2010, Tangan-Tangan Amerika Operasi Siluman di Pelbagai Belahan Dunia, (Jakarta: Global Future Institute).

Iwadhi, Rif'at al-Sayyid, 1990, Kitab al-Ummah: Fi al-Iqtisâdal-Islâmi, al-murtakazâ, al-Tauzî́, al-Istismâr.

Junaidal, Hamad Ibn Abd Rahman, 1402 H, Manahij al-Bahisin fi al-Iqtishad alIslami, Riyad: Syarikah al-'Abikan li al-Thiba'ah wa al-Naysr.

Jundi, Muhammad Al-Syahatah, 1985, Qowa'id al-Tanmiyah al-Iqtisodiyah fi alQanun al-dauli wa al-figh al-islami, (Kairo: Dar al-nahdah al-Arabiyah).

Karim, Adiwarman , 2003, Sejarah Pemikiran Ekonomi Islam, IIIT Indonesia, Jakarta.

Kasbah, Mustafa Dasuqi, Maqashid al-Syari'ah Fi Tanmiyatin wa Istismar al-Mal ma'a al-Tathbiq 'ala al-Muassasat al-Maliyah,.

Khafîf, Ali,1968, al-Milkiyah fi Syari'ati al-Islâmiah Ma'a muqâranatiha bi al-qawânîn al-'Arabîyah, Ma'had al-buhûs wa al-Dirâsât.

Malik Ben Nabi, 1974, Al-Muslim fi 'alam al-Iqtisad, (Beirut: Dar Al-Syuruq).

Muhammad, Abdul Mannan, 1993, Ekonomi Islam: Teori dan Praktek, PT Dana Bhakti Wakaf, Yogyakarta.

Perkins, John, 2004, Confessions of An Economic Hit Man, San Fransisco: BK: Berrett Koehler Puslishers.

Perkins, John, 2004, The Secret History of The American Empire Economic Hit Man, Jakals and The Truth About Golbal Corruption, diterjemahkan ke dalam bahasa Indonesia oleh Wawan Eko Yulianto \& Meda Satrio, (Jakarta: Ufuk Press,).

Ricardo, David Akhmad, 2004, Khadafi Jagoan Tanah Arab, (Makassar: Arus Timur.

Al-Rubi, Mahmud, 1984, Al-Minhaj al-Islami fi al-Tanmiyah al-Iqtisodiyah wa alIjtima'iyah dalam Majallat al-dirasat all-tijariyah wa al-islamiyah, (Markaz solih Abdullah Kamil li al-dirasat al-tijariyah wa al-islamiyah), nomor 3, tahun ke satu Juli 1984.

Al-Sallus, Muhammad Ali, 1964, Milkiyat al-Afrad li al-Ardhi wa manafi'uha fi alIslam, Bahsun Mansyur fi al-Mu'tamar al-Awwal li Majma' al-Buhus al-Islamiyah, al-Azhar. 
Sardar, Ziauddin \& Merryl Wyn Davies, Mengapa Orang Membenci Amerika (Why do People Hate Amerika?), Batam: Classic Press.

Surahman, M. Anwar, Marye Agung Kusmagi, 2011, 69 Konspirasi Dunia versi Wikileaks, (Jakarta: Penerbit Raih Asa Sukses).

Al-Syarqawi, Jamil, Quyud al-Milkiyah li al-Mashlahah al-'Ammah fi al-Syari'ah al-Islamiyah, Majallah al-Huquq wa al-Syari'ah, Kulliyat al-Huquq wa al-Syari'ah Jami'ah al-Kuwait, al-Sanah al-salitsah,, al-'adad al-Sani, Sya'ban 1398 H, Juni 1978.

AL-Syatibi, Abu Ishak, al-Muwafaqat, Beirut: Dar al-Ma'rifah, 1415H/1994M.

AL-Syukairy, Abd al-Haq, 1408 H, al-Tanmiyah al-Iqtishadiyah fi al-Minhaj al-Islami (kitab al-Ummah), Qatar: Mathobi' Muasasatu al-Kholij li al-Nasyr wa al-Thiba'ah).

Tamburaka, Apriadi Tamburaka, 2011, Revolusi Timur Tengah Kejatuhan para penguasa otoriter di Negara-Negara Timur Tengah, (Yogyakarta: Penerbit NARASI, 